\title{
Retraction
}

\section{Retracted: Case Study of Carbon Emissions from a Building's Life Cycle Based on BIM and Ecotect}

\author{
Advances in Materials Science and Engineering \\ Received 26 January 2017; Accepted 26 January 2017; Published 5 April 2017 \\ Copyright (C) 2017 Advances in Materials Science and Engineering. This is an open access article distributed under the Creative \\ Commons Attribution License, which permits unrestricted use, distribution, and reproduction in any medium, provided the \\ original work is properly cited.
}

Advances in Materials Science and Engineering has retracted the article titled "Case Study of Carbon Emissions from a Building's Life Cycle Based on BIM and Ecotect" [1]. The article was previously published as Peng C, "Calculation of a building's life cycle carbon emissions based on Ecotect and building information modeling," (2016), Journal of Cleaner Production, Part 1112, pp. 453-465. doi: 10.1016/j.jclepro.2015 .08 .078 .

\section{References}

[1] C. Peng and X. Wu, "Case study of carbon emissions from a building's life cycle based on BIM and Ecotect," Advances in Materials Science and Engineering, vol. 2015, Article ID 954651, 15 pages, 2015. 